\title{
A STUDY ON ENVIRONMENTAL ETHICS AMONG THE TEACHER EDUCATORS OF KUVEMPU UNIVERSITY
}

\author{
Dr. Shivakumar GS \\ Principal, Kumadvathi College of Education, Shikaripura, Karnataka-577427, India
}

Article DOI: https://doi.org/10.36713/epra9218

DOI No: 10.36713/epra9218

\begin{abstract}
Every human being has the right to decent life but today there are elements in our environment that tend to militate against the attainment and enjoyment of such a life. The exacerbation of the pollution of environment can cause untold misery. Unhappiness and suffering to human beings, simply because of our lack of concerns for the common good and the absence of sense of responsibility and ethics for sustaining a balanced eco-system. If we are to aspire to a better quality of life - one which will ensure freedom from want, from disease and from fear itself, then we must all join hands to stem the increasing toxification of this earth. What we need in order to defuse this environmental time bomb is immediate concerted action of all the people, but such needed action will come only if we reorient such citizenry values, i.e., imbibe them with proper awareness and values (ethics), specifically those that will lead to a greater concern for preserving balance in the ecosystem, besides teaching them how to save the environment from further degradation, and to help, make it more healthful and progressive place to live in, springs from a strong sense of social responsibility.
\end{abstract}

KEYWORD: Environmental Ethics

\section{INTRODUCTION}

Nature is the greatest gift of God on the earth. It is capable of providing man with everything that he needs, not only for self-sustenance, but also for making his life fully comfortable. Nature and human kind have formed indivisible parts of the life support system. When we look at the beauty of nature, we find that five elements (Space, Air, Fire, Water, and Earth) provide the foundation for the entire physical world and Ayurveda recognizes these five elements which are interconnected. If there is deterioration in any one, it affects the other four elements and natural environment at large. It was liberality of "Mother Nature" to allow man free access to her precious resources. However, man's desire for happiness and comforts has led him to utilize nature's free goods to the extent of reducing its natural capacities for self-stabilization.

In the $20^{\text {th }}$ century the environmental issues have gained greater concern. Environment includes natural atmosphere and built environment. The natural atmosphere is being polluted due to the unnatural factors. Human beings are more responsible for environmental pollution than the natural causes like a volcanic eruption. According to environmental ethics, humans are part of natural community rather than managers of it. Such an ethic places limit on human activities such as uncontrolled resource use that may adversely affect the natural community. Environmental ethics are much more important than environmental laws as it is internal force. It sensitizes a human being for various environmental issues as the man is controlled here by an internal force and not by the fear of punishment. Education is a powerful tool in the hands of society to bring sensitivity among human beings.

\section{SPECIFIC OBJECTIVES OF THE STUDY}

a) To find out the environmental ethics among the male and female teacher educators of Kuvempu University.

b) To find out the environmental ethics among the Rural and Urban B.Ed college teacher educators of Kuvempu University.

c) To find out the environmental ethics among the male and female teacher educators of Aided and Un-Aided B.Ed colleges of Kuvempu University.

\section{METHODOLOGY}

There is great need to plan and design a procedure and method for any research work. In any research, methodology makes the most important contribution. It is the backbone of the research 
problems. There are numerous methods and procedures to be applied in any scientific investigation, but it is the nature of problem under investigation, which determines the selection of a particular method of study and the plan and procedure of a research design structure and strategy of investigation to obtain answers to research questions and to control variance. The plan is the overall scheme of the research. It includes an outline of everything that the investigator will do from writing the hypotheses and their operational implications to final analysis of the data. A plan tells us what type of statistical analysis to use and outlines possible conclusions to be drawn from statistical analysis

This session represents the statement of the problem, operational definitions, Selection of variables, discussions, definition of variables, hypotheses formulated, description of tools used for collection of data, sampling, administration and scoring of the tests and statistical analysis for the data.

\section{HYPOTHESIS}

1. There is a significant difference in the environmental ethics among the Rural and Urban B.Ed college teacher educators.

2. There is a significant difference in the environmental ethics among the Aided and UnAided B.Ed college teacher educators of Kuvempu University.

3. There is a significant difference in the environmental ethics among the male and female teacher educators of Kuvempu University.

\section{DESIGN OF THE STUDY \\ Method of Research}

1. The decision about the methods of research depends upon the problem selected and kind of the data necessary for its objectives. Moreover, a systematic procedure is required as it helps the researcher to test the hypotheses of the study under investigation
2. The proposed study involves Normative survey method as it was aimed to study the Environmental Ethics and Environmental Awareness of Teacher Educators of Kuvempu University.

\section{Sample and Sampling Procedure}

Sampling is a process used in statistical analysis in which a predetermined number of observations are taken from a larger population. The methodology used to sample from a larger population depends on the type of analysis being performed, but it may include simple random sampling or systematic sampling.

The population is the portion of the universe to which a researcher has admittance. The sample is relatively a small number of individuals, objects or events selected for analysis in order to find out something about entire population from which it is selected. A sample is a miniature picture of the entire group or aggregate from which it has been taken. A sample, in other words, is a smaller representation of the whole.

For the purpose of the present study, entire population is to be made the subject for data collection. The entire population here refers to all the teacher educators of B.Ed colleges of Kuvempu University.

\section{Population}

Population for the present study constitutes the teacher educators of of B.Ed colleges of Kuvempu University. There are about 18 B.Ed colleges are coming under the Kuvempu University. Consideration was given to entire population is to be made the subject for data collection.

\section{Sample}

Based on the variables of the present study, consideration is given to entire population is to be made the subject for data collection. The entire population here refers to all the teacher educators of B.Ed colleges of Kuvempu University. 


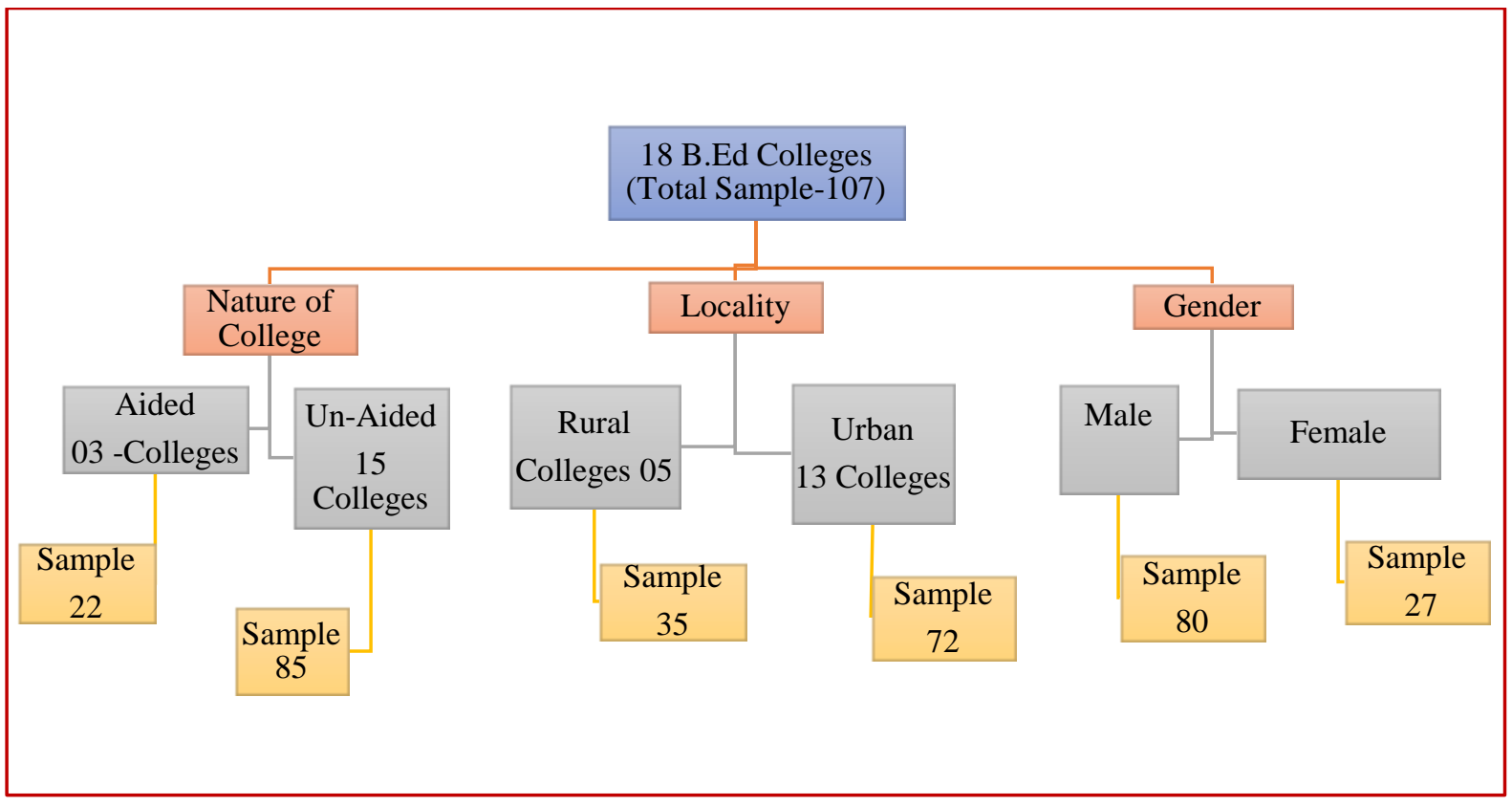

Figure 1: Flow chart of Sampling

Tools Used for the Collection of the Data

The selection of a tool for a particular depends upon various considerations such as objectives of the study, availability of suitable tools, personal competence of the researcher to administer, scoring procedure or interpreting norms for the results and reliability and validity of the scale for the selected sample.

Tools are means for collection of data for interpretation and to explore new fields. There are many research tools and methods but the selection of a tool is a difficult task in research and is dependent upon various considerations such as objectives for the study, hypothesis of the study, availability of time, personal competence of the investigator to administer the tests, scoring and interpretation of the results. The researchers are required to make a wise and judicious choice and should select only those tools which may be suitable to meet the requirements of the study. Each tool is suitable for the collection of certain type of information. The researcher has to select from the available tools, which will provide data one seeks for testing hypotheses.

Based on the review of related literature and personal experience and also keeping in view the variables and the objectives of the study the, investigator has chosen the following tools for the collection of relevant data.

\section{- Environmental Ethics Scale by Haseen Taj} (English):

Environmental Ethics refers to the responsibility to understand the environmental consequences of our consumption, and need to recognize our individual and social responsibility to stud conserve natural resources and protect the earth for future generations. An environmental ethics is basically a human ethics based on social justice for all without discrimination of race, sex, religion, ideology, caste, region or nation.

This scale assesses the social responsibility and environmental ethics of individuals and is also used to modify and develop the ethics in case of lack of concern of ethics towards environment among individuals and society collectively. It consists of 45 statements, out of 45 items 8 are meant to assess ethics in favourable direction and 37 in unfavourable direction, with 3 responses of I agree absolutely, I slightly agree and I don't agree. The score of 3, 2 and 1 were assigned to favourable, whereas the scores of 1, 2 and 3 were assigned to unfavourable statements.

\section{Scoring of the Environmental Ethics Scale:}

For positive statements a score of three (3) is given to "I agree absolutely" response, a score of two (2) for "slightly agree" response and a score of one (1) for "don't agree ee response. For negative statements, the scoring is reversed. The ethics score of an individual is the sum total of scores. According to the scoring principle the maximum possible score for this scale is 135 and the minimum possible score is 45. Higher score represents the positive environmental ethics and vice versa.

\section{Statistical Techniques Used for Analysis of the Data}

The data were analyzed through certain descriptive statistics. The normality of the data (Environmental Ethics scores and Environmental awareness scores) is assessed by calculating Mean 
and Standard Deviations, test of significance, i.e., paired " $\mathrm{t}$ " test was calculated to compare the independent variables in between the groups

The researcher has used the following statistical techniques for the analysis of the data.

a) Mean and Standard Deviations were calculated for the scores in the group.

b) Test of Significance i.e paired " $t$ " test was used to compare the different groups in respect of dependent variable.

\section{TESTING OF HYPOTHESIS}

The hypothesis formulated were tested using the test of significance of i.e., paired " $t$ " test.

\section{Hypothesis-1:}

There is no significant difference in the environmental ethics among the Rural and Urban B.Ed college teacher educators of Kuvempu University.

Table-1: Significance of Difference in Mean environmental ethics among the Rural and Urban B.Ed college teacher educators of Kuvempu University.

\begin{tabular}{|c|c|c|c|c|c|}
\hline \multirow{2}{*}{ Particulars } & \multirow{2}{*}{ N } & \multicolumn{2}{|c|}{ Environmental Ethics Score } & $\begin{array}{c}\text { Mean } \\
\text { Difference }\end{array}$ & t-Value \\
\cline { 2 - 5 } & & Mean & SD & & \\
\hline Rural & 35 & 75.67 & 5.73 & $0.66^{*}$ \\
\hline Urban & 72 & 74.89 & 9.8 & & \\
\hline
\end{tabular}

*Non-Significant at 0.05 Level of Significance

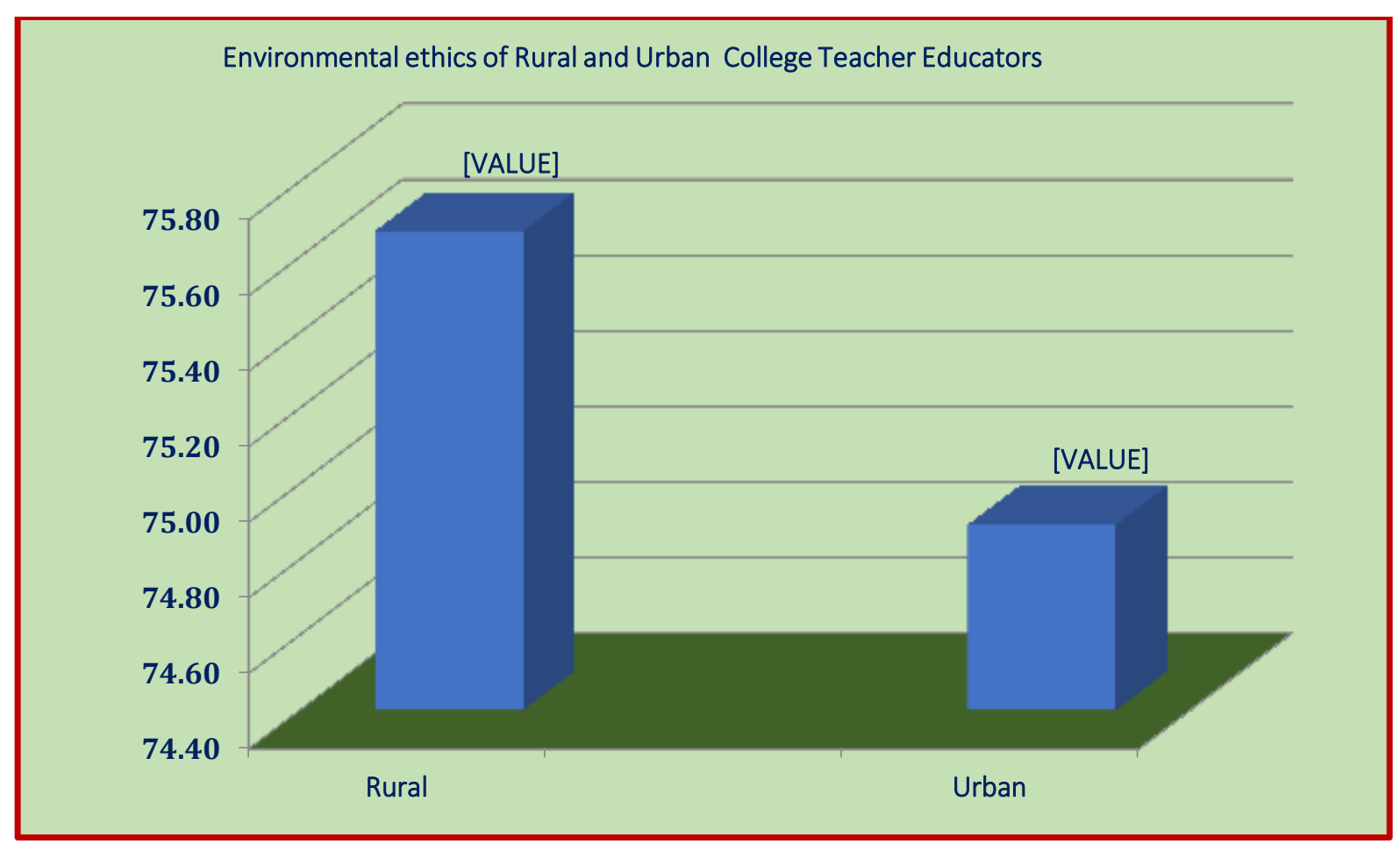

Figure 02: Bar Graph showing the Environmental ethics of Rural and Urban College Teacher Educators 
The " $\mathrm{t}$ " test results in the table 01 and figure 01 depicts that, no significant difference in the Mean Environmental Ethics scores among the Rural and Urban B.Ed College Teacher Educators of Kuvempu University. Therefore, the Hypothesis, which states that there is no significant difference in the environmental ethics among the Rural and Urban B.Ed college teacher educators of Kuvempu University was accepted. From this it is concluded that, the teachers educators of Rural and Urban B.Ed colleges Kuvempu University do not differ in their Environmental ethics.

Hypothesis-2:

There is no significant difference in the environmental ethics among the Aided and UnAided B.Ed college teacher educators of Kuvempu University.

Table:2 Significance of Difference in Mean environmental ethics among the Aided and Un-Aided B.Ed college teacher educators of Kuvempu University.

\begin{tabular}{|c|c|c|c|c|c|}
\hline \multirow{2}{*}{ Particulars } & \multirow{2}{*}{$\mathbf{N}$} & \multicolumn{2}{|c|}{ Environmental Ethics Score } & $\begin{array}{c}\text { Mean } \\
\text { Difference }\end{array}$ & t-Value \\
\cline { 3 - 4 } & & Mean & SD & \multirow{2}{*}{7.01} & \multirow{2}{*}{$6.42^{*}$} \\
\hline \multirow{2}{*}{ Aided } & 22 & 76.29 & 5.62 & \\
\hline$\ldots$ & 85 & 69.58 & 9.85 & \\
\hline
\end{tabular}

*Significant at 0.01 Level of Significance

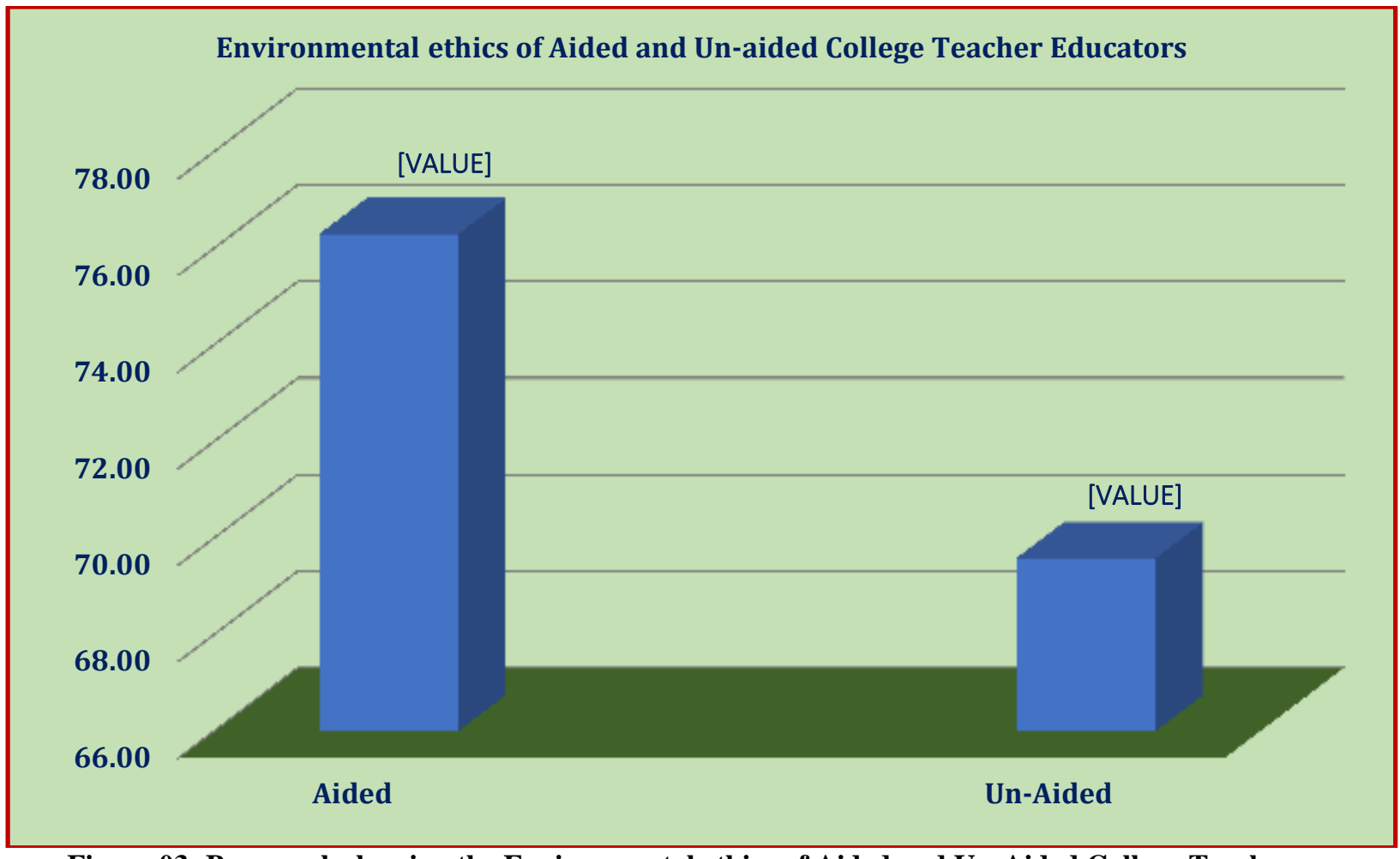

Figure 03: Bar graph showing the Environmental ethics of Aided and Un-Aided College Teacher Educators 
The " $\mathrm{t}$ " test results in the table 02 and figure 02 depicts that, the obtained " $\mathrm{t}$ " value is 6.42 is significant at 0.01 level of significance and it is more than the table value 2.58 . Hence the hypothesis is rejected.

Further when the means are compared, we can conclude that, Environmental Ethics of Aided B.Ed College Teacher Educators $(M=76.29)$ is found to be better than the Un-Aid ed B.Ed College Teacher Educators $(\mathrm{M}=69.58)$. The higher Environmental Ethics could be attributed to their wider social, better exposure to information via all kinds of media and as well as the enhanced opportunities to participate in various Government and non-governmental programmes of compulsorily at state, National and International Levels.

\section{Hypothesis-3:}

There is no significant difference in the environmental ethics among the male and female teacher educators of Kuvempu University.

Table:3 Significance of Difference in Mean environmental ethics among the male and female teacher educators of Kuvempu University.

\begin{tabular}{|c|c|c|c|c|c|}
\hline \multirow{2}{*}{ Particulars } & \multirow{2}{*}{$\mathbf{N}$} & \multicolumn{2}{|c|}{ Environmental Ethics Score } & \multirow[t]{2}{*}{$\begin{array}{c}\text { Mean } \\
\text { Difference }\end{array}$} & t-Value \\
\hline & & Mean & SD & & \multirow{3}{*}{$0.76^{*}$} \\
\hline Male & 27 & 75.23 & 10.47 & \multirow[t]{2}{*}{0.63} & \\
\hline Female & 80 & 75.86 & 5.6 & & \\
\hline
\end{tabular}

*Non-Significant at 0.05 level of significance

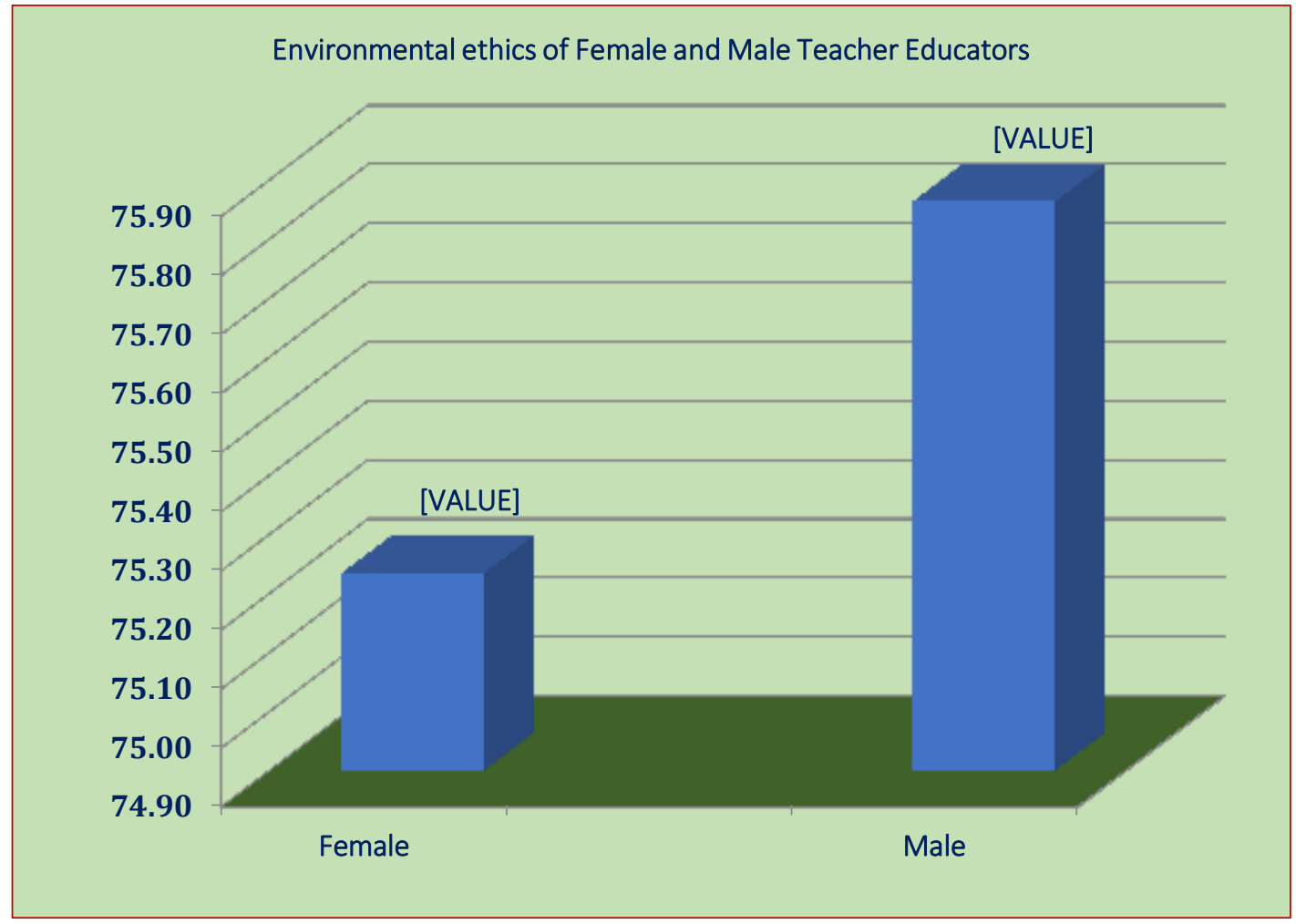

Figure 04: Bar graph showing the Environmental ethics of Female and Male Teacher Educators 
It is evident for the data of Table-03 and Figure-03, the obtained " $t$ " value is 0.76 is non-significant at 0.05 level and it is less than the table value 1.96 . Hence the hypothesis is accepted.

Further when the means are compared, we can conclude that, the Environmental ethics of Male Teacher Educators $(\mathrm{M}=75.23)$ and Female Teacher Educators( $M=75.86)$ there is no significance difference. From this it is concluded that there is no significance difference in the Environmental ethics among the Male and Female Teacher Educators of Kuvempu University.

Main Findings and Conclusions of the Study

The followings are the main findings of the study.

1. There is a significant difference in the environmental ethics among the Aided and Un-Aided B.Ed college teacher educators of Kuvempu University. The environmental ethics of aided B.Ed College Teacher Educators is found to be better

2. The higher Environmental Ethics could be attributed to their wider social, better exposure to information via all kinds of media and as well as the enhanced opportunities to participate in various Government and non-governmental programmes of compulsorily at state, National and International Levels.

\section{Educational Implications of the Study}

The present study is undertaken to determine the relationship of environmental ethics and environmental Awareness in human beings. The findings of the present study have ample implications for the teachers, media experts, policy makers, educational administrators, curriculum planners, government and other professionals working in the field of the environment.

- These implications are presented in the following section: The research suggests that environmental ethics is the necessity of the hour. Inculcating responsibility, scientific and positive attitudes about the environment among the student teachers is the main duty of the teacher educators and to carry out this noble task, education is the great tool. If positive attitudes related to environment are developed in student teachers, these attitudes will be transmitted to future generations also by them.

- The findings of the present study reveal that the unaided college Teacher educators do not have high environmental ethics. The activities for enhancing environmental ethics, responsibility and attitudes are inadequate in our educational institutions. Therefore, it is very essential that necessary strategic planning should be undertaken. So that the teacher educators themselves get motivated in this regard.

\section{REFERENCES}

1. Balachandran, S. (2013). A study of environmental awareness and environmental ethics among the secondary and higher secondary school students of greater Mumbai. (Doctoral Dissertation), Shri Jagdish Prasad Jhabarmal Tibarewala University, Rajasthan.

2. Baruah, P. \& Devi, B. (2014). Environmental ethics and women in Assamese community: A case study in Guwahati city, Assam. International Journal of Informative \& Futuristic Research, 1(8), 91-97.

3. Gupta, S., Gupta, S. And Chauhan, J. (2011). A comparative study of the level of environmental ethics among adolescent students. Journal of Teacher Education and Research. Vol. 6. No.1.

4. Pradhan, G.C. (2002) Environmental Awareness among secondary school Teachers. Experiments in Education, 03-05.

5. Santhosh Kumar Rout., Sukirti Agarwal, (2006) Environmental Awareness and Environmental Awareness of students at high school level. Edutracks 6, 1, 25-26,

6. $Y u$, M. And Lei, Y. (2007). Environmental values and ethics. Environment and Development. Vol. II. www.eolss.net

\section{WEB-LINK}

1. http://www.env-ethics.com/

2. https://plato.stanford.edu/entries/ethicsenvironmental/

3. https://en.wikipedia.org/wiki/Environmental_ethi cs

4. https://en.wikipedia.org/wiki/Environmentalism 